\title{
"But in the Thunder, I Still Hear Thor": The Character Athelstan as a Narrative Focal Point in the Series Vikings
}

\author{
Margaret Steenbakker
}

check for updates

Citation: Steenbakker, Margaret. 2021. "But in the Thunder, I Still Hear Thor": The Character Athelstan as a Narrative Focal Point in the Series Vikings. Religions 12: 203. https:// doi.org/10.3390/rel12030203

Academic Editor: Antonio

Muñoz-García

Received: 27 February 2021

Accepted: 16 March 2021

Published: 18 March 2021

Publisher's Note: MDPI stays neutral with regard to jurisdictional claims in published maps and institutional affiliations.

Copyright: (C) 2021 by the author. Licensee MDPI, Basel, Switzerland. This article is an open access article distributed under the terms and conditions of the Creative Commons Attribution (CC BY) license (https:/ / creativecommons.org/licenses/by/ $4.0 /)$.
Tilburg School of Humanities and Digital Sciences, Tilburg University, 5037 AB Tilburg, The Netherlands; margaretsteenbakker@hotmail.com

\begin{abstract}
This article explores the way the character Athelstan serves as a narrative focal point in the popular television series Vikings. Using this series as its main case study, it addresses the question of the ways in which the character functions as a synthesis between the two opposing world views of Christianity and Norse religion that are present in the series. After establishing that Vikings is a prime example of the trend to romanticize Viking culture in popular culture, I will argue that while the character Athelstan functions as a narrative focal point in which the worlds can be united and are united for a while, his eventual death when he has reverted back to Christianity shows that the series ultimately favors Viking culture and paints a very negative picture of (medieval) Christianity indeed.
\end{abstract}

Keywords: Vikings; Christianity; narrative analysis; Athelstan; Norse mythology

The year is 793 and you are a young, yet ambitious, Viking man, named Ragnar Lothbrok. Every year, you raid in the Baltic, but you are convinced that raiding to the West could be worth your while. When you fail to convince the Earl that you have sworn allegiance to, you decide to bring a couple of trusted men and go yourself.

This is the beginning of the popular television series Vikings, which is of a historical nature and shows events that have been featured in Norse folklore and takes place in real locations. The series can be situated within an ongoing trend of portraying Viking society in a fictionalized and romanticized manner (Puchalska 2015; McLeod 2019; Erwich 2020). Viking culture has developed a profound presence not only on television, but also in novels, comics and in music (Trafford and Pluskowski 2007; Trafford 2020). The television series Vikings can be seen as a prime example of this trend. What sets this series apart, however, is the prominent clash between two belief systems that are featured within it, rather than a focus solely on romanticizing ancient Norse culture and religion.

The main protagonist of the series, Ragnar Lothbrok-and later on, his offspring-is a Norse Viking hero. It is believed that he is an actual historical figure and many sagas have been written about him (Erwich 2020). Ragnar Lothbrok is notorious for having been a thorn in the eye of both English and French kings because of his continuous raiding of those shores. The series follows him from his humble beginnings as a farmer, throughout his rise to power as a king, to his eventual downfall. It then continues to follow the lives of his sons.

Much can be said about the historical nature of the series, with Puchalska (2015) pointing out many historical inaccuracies, for instance, from persons and dates that are incorrect to anachronistic armor, to name but a few. Tromans (2015), moreover, points out that Vikings strays from its "source text", by discarding many of its more mythical aspects and instead placing Ragnar Lothbrok front and center. Moreover, the series begins the Viking age a good 40 years earlier than its actual start. Much more can be said about the historical (in)accuracies of the series. This will, however, not be the focus of this article.

As a viewer, one becomes immersed in a world that features two opposing religious and cultural systems. That of Christianity, on the one hand, which is featured in both medieval English and French societies, for instance, and that of the Norsemen, which deals with the cultural and religious imagery of the Norse gods and old Norse societies. Both 
cultures are juxtaposed by the series. The Norse culture is, for instance, more egalitarian than its Christian counterparts and features a different justice system. Another difference is that Christian societies are monotheistic, whereas Norse societies are polytheistic. Most characters from either side of the cultural "divide" deem their cultural and religious beliefs to be superior to that of the other. The series presents a romanticized take on both types of societies, which does not do justice to historical facts (Saunders 2014; Puchalska 2015).

This supposed gap between the two worlds is somewhat closed by the introduction and subsequent character development of the monk Athelstan, who is an English monk that is taken captive on Ragnar's very first raid along the English coast. Rather than killing him, like they did with most of his peers, Ragnar decides to take Athelstan back home with him and arranges for Athelstan to become his personal slave. At first, the differences between Athelstan and the Norsemen are striking. However, over time, he becomes a valued member of their society and gains the Norsemen's trust. In doing this, he also learns more about their culture and their religious system and eventually becomes a Viking himself, fully accepting the Norse way of life.

Athelstan eventually starts incorporating elements of the Norse belief system in his spirituality, even going as far as to state that both his own, Christian God as well as the Norse gods are very much alive and real to him. He sees their presence everywhere, and as his character develops further, not only does his belief system incorporate both the Christian God as well as the Norse gods, but eventually, he fully accepts the Norse belief system. Interestingly enough, after he is captured on English shores, he reverts back to Christianity and ends up becoming a martyr at the hands of his Norse kinsman Flóki.

In my article, I will focus on this specific character and the role he plays in the television series as a synthesis of two opposing world views within the series. As such, I will perform a narrative analysis (Bal 1985; Herman and Vervaeck 2005; Verstraten 2009) of the way Athelstan becomes a narrative focal point in which the differences and similarities between the two worlds come to the fore most strongly.

Moreover, I will pay special attention to the Christophoric elements (Bosman 2017, 2019) that can be associated with the character Athelstan as the series progresses, such as his crucifixion, the stigmata he ends up having on his hands and several hallucinations he is shown having. By doing this, I will provide an insight into the question of how medieval Christianity is portrayed and culturally appropriated in popular media-in this case, in the television series Vikings — especially when contrasted to (a romanticized version of) Viking religion and culture.

In this article, I will first give an overview of the television series Vikings (Section 1). I will then discuss the character Athelstan in more depth (Section 2) and analyze key scenes from the series (Section 3). The article will end with my conclusions.

\section{The Vikings Television Series}

Vikings takes place at the beginning of the Viking era in Scandinavia in the early ninth century. It follows the story of Ragnar Lothbrok and, subsequently, that of his sons. The series has won several awards and has been nominated for many more (IMDb n.d.) and has received both praise and criticism from critics (O'Neill 2014; Holland 2019).

At the beginning of the series, the men of Kattegat are sent east on an annual raid by their chosen "Jarl" (earl) Haraldson. This is a title held by the "prominent men below the kings in Viking-age Scandinavia" (Holman 2003, p. 81). Ragnar joins in on these raids, but he also feels a desire to travel west, as he has heard many stories of the riches that can be found there. As such, he tries to find support for his desire to travel in another direction and finds it. As Jarl Haraldson is against his plans to travel west, Ragnar has a boat built in secret by his friend Flóki, and with a couple of men, he secretly travels west anyway, where they stumble upon the monastery at Lindisfarne, in Northumbria. It is here that Ragnar first meets the monk Athelstan, and unlike his peers, he lets Athelstan live and decides to take the monk with him as a slave. Athelstan quickly becomes a central character within 
the series, and through conversations he has with Ragnar, an exchange between Christian and Norse religion begins.

Tensions between Jarl Haraldson and Ragnar rise and eventually lead to a fight between the two, in which Ragnar, although badly wounded himself, mortally injures the Jarl and kills him, leaving Ragnar the new Jarl of Kattegat. Throughout this time, Athelstan can be seen to overcome his aversion to Norse religion and slowly adapt to his new surroundings. This then takes an even deeper turn when the Viking community travels to Uppsala, bringing sacrifices. Athelstan was supposed to be sacrificed as well, unbeknownst to him, but even though he has accepted Norse religion, he still holds his Christian faith as well and therefore cannot be sacrificed.

As Jarl Ragnar continues raiding the English shores, he eventually tries to establish a Norse community there, as the English soil is fertile and good for agriculture. Ragnar is eventually stopped by the English King Ecbert, who has forced an alliance with King Aelle. Ragnar is defeated and goes back to Kattegat. During this time, he has decided to take a second wife in Aslaug, as he feels that this will increase his chances of having another son. This leaves his relationship with his first wife, Lagertha, in danger. She chooses to divorce Ragnar and leaves him, together with their son Björn, who goes with his mother. However, not all is going in a negative direction for Ragnar during this time, as he is also able to defeat one of his enemies, King Horik, and take over his kingdom. This makes Ragnar king and puts him in a very powerful position.

Athelstan, who has now fully adapted to life as a Viking, eventually manages to convince Ragnar to pursue a raid on Paris. Flóki has some increasing issues with Athelstan living a fully Viking life. He does not trust Athelstan and sees him as a Christian still, rather than as a member of their community. While the raid on Paris is successful, the Viking settlement on the English shores is destroyed on King Ecbert's orders, which is a setback for the Vikings, nonetheless. Ragnar keeps this information to himself rather than sharing it with his kinsmen. Athelstan is eventually killed by Flóki and dies a martyr.

The events previously described can be seen to lead up to Ragnar's eventual downfall at the hands of King Ecbert and King Aelle. It is King Aelle who eventually kills Ragnar by throwing him in a snake pit. The series then continues to follow the lives of Ragnar's sons and their adventures in England, Scandinavia and the Mediterranean.

\section{The Character Athelstan}

Athelstan is one of the main characters in Vikings and is introduced to the viewer as a monk at Lindisfarne Monastery in Northumbria. Although it is never mentioned explicitly, we can assume that Athelstan belonged to the Benedictine order, as this would be historically correct (Tristram n.d.). When the Vikings raided the monastery, most of Athelstan's peers were slain, but Athelstan was not. He managed to capture Ragnar's interest because he spoke some of his language. This made Ragnar decide to take Athelstan back home and turn him into a slave because he assumed Athelstan might be able to give him some valuable information for his next raid, as Athelstan is familiar with the land.

Athelstan struggled to adapt to his new living conditions at first. At first, he clung desperately to his Christian beliefs, but over time, these beliefs became less firm than they once were and he begins doubting his faith in the Christian God. As he becomes a more valued member of Norse society, he learns about their religious beliefs as well, such as the legend Ragnarök, as well as various tales about the gods and their many deeds.

Over time, Athelstan becomes more and more assimilated into Viking society, and when asked about his beliefs, he lies and tells people that he is no longer a Christian and has fully accepted the Norse religion. Ragnar is one of the few people who know that Athelstan is still a Christian. When Ragnar plans a visit to the holy place Uppsala, Athelstan is asked to come along. Athelstan accepts the invitation, and while at Uppsala, many ask him whether he is still a Christian. He denies this. However, one of the primary rituals at this holy place is a human sacrifice. 
When Athelstan is approached by the Seer, he denies Christ three times, but when it is revealed to him that he was brought there to serve as a human sacrifice, Athelstan is shocked and touches the cross that he has hidden in his sleeve. The Seer notices this and knows that he is still a Christian; therefore, his sacrifice is unacceptable.

With the passing of years, however, Athelstan does indeed convert fully to Norse religion and eventually starts raiding with the other Vikings as well. While on his first raid, Athelstan does not hesitate to help the Vikings with killing any enemies. However, when he stumbles upon a Bible at an abbey, Athelstan is brought to reflect upon his actions. He eventually takes the Bible with him, and although this act does not change his actions of beliefs immediately, he does receive a vision of crucifixion a while after having taken the Bible. This can be seen as a foreshadowing of what is about to happen.

While hunting, Athelstan and several other Vikings are captured and Athelstan is indeed crucified. He is eventually saved by King Ecbert, who thinks he can be of value and therefore wants his life to be spared. His wounds are mended and he is kept close by King Ecbert, who even asks him for advice on royal business from time to time. Athelstan begins having visions such as that of his crucifixion. He begins seeing the virgin Mary and some kind of Devilesque beast. Even though he attends mass again, he lies about taking the bread of Christ and spits it out after having taken it. This shows that paganism is still an important factor in his religious beliefs.

When the Vikings raid the English shores again, Athelstan is eventually sent to visit Ragnar and negotiate peace. This leads to a conversation about each other's gods between the two of them. After this visit, Athelstan has a brief affair with Judith, the wife of King Ecbert's son, Prince Aethelwulf. She becomes pregnant with his child as a result. After the treaty, Athelstan is faced with the choice between staying with King Ecbert or going back with the Vikings. After much consideration, he chooses the latter. This choice will eventually result in his death at the hands of Flóki, who comes to him when he is praying and kills him.

\section{Analysis of Key Scenes}

In order to analyze the role Athelstan plays in the series, I will perform a narrative analysis (Bal 1985; Herman and Vervaeck 2005; Verstraten 2009) of the way in which Athelstan becomes a narrative focal point in which the differences and similarities between the two worlds come to the fore. As a method, narrative analysis is related to the structuralist movement in literary studies and is, therefore, a method highly suited to analyze narratives as they come to the fore in novels, but also in other media that employ some form of storytelling, such as television series, and has indeed been used in this way. What this means for the article at hand is that I have looked at actors within the series-in this case, Athelstan-power relations and the way these shift with regards to Athelstan's religious development and the way in which Athelstan develops as a character throughout the sequential ordering of the series, especially during a few key scenes.

There are many interesting scenes relating to Athelstan. So many, in fact, that discussing all of them is beyond the scope of this article. Instead, I shall focus on a few key scenes that indicate just what role the character Athelstan played within this fictional Viking society and what function he has within the narrative world of Vikings. These scenes have been selected based on the following criteria:

- The character Athelstan had to be in them;

- They had to express something about his worldviews, either directly or indirectly. Therefore, scenes in which Athelstan was looking after Ragnar's children, for instance, were not selected;

- Alternatively, they had to express something about how Athelstan's environment responds to his worldviews.

Only scenes that met these criteria were selected. This still came down to too great a number of scenes to properly discuss in the article at hand. Therefore, a further selection had to be made. Those scenes that most clearly showed the changes in Athelstan's world- 
views were, therefore, selected, so as to indicate the religious life story of the character, if you will. With these criteria, the selected scenes are representatives of Athelstan's changing worldviews and the way his environment responds to these worldviews. However, the provided selection is not a definitive or exhaustive list, as this would be beyond the scope of this article.

\subsection{Being Invited to a Threesome}

A first scene to look at takes place during season 1, episode 3 (S1E3). In this episode, Athelstan is brought home by Ragnar and introduced to his family. When he meets Ragnar's children, Björn and Gyda, they marvel at his strange appearance and his strange beliefs, which clearly set him apart from them. Björn, for instance, asks Athelstan what is wrong with his head, because of his tonsure. ${ }^{1}$ Athelstan replies that this marks them out as monks. Gyda then asks him which god he likes best and he replies that there is only one God. At the very beginning of the series, then, this simple sentence marks out one of the key differences between Nordic and Christian societies, namely their belief systems. Nordic people have a polytheistic religion, whereas Christians are monotheistic (Saunders 2014).

As this scene ends, we move into the scene that is of relevance here. This begins with Athelstan reading aloud from his Bible, while in the background, the sounds of Ragnar and Lagertha having sex can be heard. The camera zooms in on the page Athelstan is looking at, which is from the gospel of St. John, the book Athelstan saved during the raid at Lindisfarne. It says Ioannus in elaborate lettering at the top of the page.

From where he is located, Athelstan can see Ragnar and Lagertha having sex. We see him glancing over and then quickly going back to his reading. After a little while, the moaning ceases, and Ragnar and Lagertha appear. They ask him to join them, to which he replies: "I am a monk. I have taken vows of celibacy. I cannot touch a woman. I never have." This is not entirely correct, as Benedictine monks take three vows, namely stability, fidelity to the monastic way of life and obedience, and Athelstan can be assumed to be of the Benedictine order considering the monastery at Lindisfarne that he was taken from. However, poverty and chastity are implied within the Benedictine order (McClure n.d.), so it is only logical that Athelstan would, from the perspective of his religious views, refuse this offer from Lagertha and Ragnar nonetheless.

Lagertha responds to this by posing seductively and showing Athelstan a large part of one of her legs. He averts his eyes. Ragnar then asks him: "Wouldn't you like to", and Athelstan says that "It would be a sin." Ragnar asks: "Who would know?", and Athelstan says: "God would know." Lagertha then asks: "What if he looked the other way?". Athelstan does not respond to this question anymore. Instead, he starts praying, reciting the paternoster in Latin. This is the first time in the series that we hear Athelstan pray. Ragnar then says: "Go to sleep then, with your God", after which Ragnar and Lagertha leave Athelstan alone and the scene ends. The fact that Athelstan first starts praying because he receives an offer of sex, and not because of any of the hardships he has faced thus far, is telling of the way in which the series frames the differing attitudes towards sex with regards to Athelstan and, by extension through him at this point in the series, Christian and Norse societies. Where the latter is seen as being more sex-friendly, the former is being portrayed as having a very pessimistic attitude towards sex indeed (Raffield et al. 2017; Bullough 1977).

Before Ragnar and Lagertha approach Athelstan to join them, Athelstan is already set apart as someone who is different. He is, of course, quite literally a stranger, who has been taken from another country, but he also has different beliefs and different looks, as has been pointed out by his interactions with Björn and Gyda, Ragnar's children. It has been made very clear that Athelstan does not belong in Viking society and that he is a stranger to their customs, only believing in one God, for instance, rather than in their many gods.

1 The Encyclopedia Britannica gives the following definition: Tonsure is a practice in which part of or all hair on the scalp is shaven. This can be seen as a sign of religious devotion, or humility. Moreover, it marks monks out as people who are different from the rest of society, as they do not adhere to worldly things and are devoted to the realm of religion, see also (Phelpstead 2007). 
After he has been established as someone who is different, the episode moves into the sex scene-or rather, the declined sex scene, as Athelstan refuses to accept Ragnar and Lagertha's offer on grounds of his religious beliefs. The scene shows him as being quite firm in his beliefs, after he is being pressed several times about whether he would not like to join them, which even goes so far as Lagertha showing part of her body in an attempt to seduce Athelstan and getting him to (temporarily) relinquish his beliefs for their pleasure. The scene further sets Athelstan apart from the Vikings, as Ragnar and Lagertha have an active sex life and clearly enjoy each other's company in that way, while also being open to introducing others to their bedroom if they so please. They see sex as something that is enjoyable. It is important to note that this egalitarian and feminist approach to sex, which the Vikings have in the series, is not necessarily based in historical facts, as much is still unknown about how the Vikings approached gender, gender roles and sexuality (Moen n.d.) and some evidence actually points to the contrary (Raffield et al. 2017). However, what this framing does achieve is that the contrast it provides with Athelstan's attitude towards sex frames Christians and Christian society as having a very negative and pessimistic attitude towards sex. This, too, is an attitude that is projected onto the past during the present. Athelstan states that he has taken vows of celibacy, and therefore, if he engages in sexual activity, it will be seen as sinful rather than as something that can be pleasurable.

However, this does not mean that Christians who have not taken such vows, cannot engage in and enjoy their sexuality (see, for instance: Pagels 1988). This, again, shows how the series frames the differences between Christian and Viking societies and how it romanticizes Viking society while painting a more negative picture of the Christian one. Both are not necessarily historically correct, but rather serve the overarching narrative of the series. Interestingly, this focus on spirituality and religion, which often comes to the fore throughout the series, can also be seen as a prime example of what Hoover and Echchaibi (2014) call digital religion, e.g., what we see in this series is a digital exploration of religion, rather than this exploration taking place in person, by actual people rather than fictional characters. As such, the series can be seen as a liberatory space, in line with how Pennington (2018) would characterize social media in relation to religion. It offers a place through which people can reflect on their own beliefs, away from family and friends who might not be open to these reflections.

Moreover, Lagertha's remark "What if he looked the other way" can be seen as marking the difference in their religious views as well. To Athelstan, his God is all-knowing, so there is no such thing as looking the other way, were he to accept Lagertha and Ragnar's offer. Lagertha and Ragnar do not understand this as they come from a very different religious background and do not believe in just one God, who knows all.

At this point in the series, Athelstan can be seen as serving a function of marking out the differences between the two societies. He is a stranger there, and while he does not understand many of the Vikings' ways, the Vikings also do not understand his habits and beliefs. As is illustrated by the scene previously described, this can cause friction at times, because both parties simply do not understand where the other is coming from. However, this gradually changes throughout the series and Athelstan rather becomes a figure who connects the two realms, that of medieval Christian Europe and that of the Vikings.

\subsection{Judith's Confession}

As we move along the fictional timeline sketched in Vikings, Athelstan becomes a valued member of Viking society, is no longer a slave and is invited to come along on a raid of the English coast. He accepts, but is eventually captured and crucified. However, King Ecbert saves Athelstan from dying on the cross and he is then kept at Ecbert's court, eventually becoming a confidante of the king. It is here that he meets the noblewoman Judith, who is married to Ecbert's son, Prince Aethelwulf. It is in the third season that Athelstan and Judith's relationship changes and they become romantically involved with one another. This all starts with Judith asking Athelstan to hear her confession, in S3E2: 
Judith: "I'm sure you can never forget being an artist. Nor a monk. Which is why I've come to ask you a favor. I want you to hear my confession."

Athelstan: "I was never a priest. I couldn't ..."

Judith: "Bishop Edmund, my confessor, is not here. And I must confess, or live in purgatory."

Judith seeks Athelstan out, even though Athelstan was a monk and not a priest and deems himself unqualified to hear her confession (Nieuwe Bijbelvertaling 2004). ${ }^{2}$ This does not seem to be an issue to Judith, as she claims that she must confess or live in purgatory. Athelstan then agrees, even though his religious beliefs at this point are complicated and are a mixture of Christian and Norse beliefs.

The scene then shifts and we see Athelstan sitting in the confessional, holding a necklace with a cross pendant on it, in his hand. He is not wearing any of the garments a priest or monk would wear. In fact, his clothes seem to be the same ones as those he wore in the previous scene, a simple blouse and a pair of trousers. Interestingly, in that scene, he also wore the bracelet Ragnar gave him. It can be assumed that he would also be wearing it in this scene. This makes his allegiance even more confusing, perhaps, as he is clearly holding on to a relic of his life with the Vikings. It can be seen to indicate that he has not fully left that part of his life behind him. Athelstan, then, can be seen as a figure who has one leg still in Viking society and Viking beliefs, while the other is in Christian society and beliefs. As such, he functions as a bridge between the two.

Athelstan is soon joined by Judith and she then begins her confession, which I have transcribed in full to paint a complete picture of this particular scene:

Judith: "Forgive me father, for I have sinned."

Athelstan: "In what ways have you sinned, my child?"

Judith: "I have sinned in thought, but not in deed."

Athelstan: "Then your sins are not so great as they might be."

Judith: "They are still great."

Athelstan: "What are these thoughts you've had?"

Judith: "I have dreamed of lying naked beside a man who is not my husband."

Athelstan: "And did you just lie beside him, or ..."

Judith: "We made love. And I enjoyed it very much."

Athelstan: "You've certainly sinned."

Judith: "Yes."

Athelstan: "Who is this man you lay with?"

Judith: "It was you, Athelstan."

Athelstan is shocked after having heard this confession and does not respond immediately. Judith then leaves the confessional, but when she does this, he calls out "Wait!" and comes after her. After exchanging a few more words, Athelstan kisses Judith, who kisses him back and then leaves the room. The fact that Athelstan responds with shock at first but then proceeds to kiss Judith shows that his beliefs have changed quite significantly from when we first met him in the series' first season and he still firmly held onto his Christian beliefs and the vows he had taken when he became a monk. This encounter between Athelstan and Judith shows that Athelstan no longer adheres to those same vows, even though he is not beyond using his schooling as a person of faith to hear someone's

2 Interestingly, the Bible mentions that Christians should confess their sins to one another and pray for one another (James 5:16). This has, over time, evolved into monks hearing each other's confessions around the year 500, and eventually, the practice became commonplace around the 10th century (Goris n.d.). 
confession and put their soul at ease when this is asked of him. Again, what we can see here is a result of the mixture of his life as a monk and his life with the Vikings. Those two belief systems have become a firm part of Athelstan. As such, the series can also be seen as an example of digital religion (Hoover and Echchaibi 2014), which offers viewers the opportunity to reflect on their own beliefs in a safe space, away from family and friends who may not look favorably on their faith.

\subsection{The Sacrifice in Uppsala}

This is perhaps exemplified even more strongly earlier on in the series, when Athelstan is asked to join the Vikings on their pilgrimage to Uppsala, in S1E8. The pilgrimage and feasts that take place in Uppsala are meant to give thanks to the gods, for that which they have given the Vikings. Athelstan does not know that he is brought along in order to be sacrificed. Although brutal, being chosen as a sacrifice is a great honor, especially for Athelstan, for it shows that he is now fully accepted into Vikings society. The Vikings see him as one of their own and believe that he holds the same beliefs as they do.

At the temple, Ragnar, Björn and Athelstan stop in front of a wood carving depicting the god Thor, and Björn asks Athelstan: "You know who that is, don't you?" Athelstan replies: "Of course. This is Thor, holding his hammer, Mjölnir. Who hasn't heard him beating his anvil in the storm? Who doesn't believe in mighty Thor, slayer of frost and fire?" The fact that Athelstan answers Björn's question in such a matter-of-fact manner shows that he has gained an extensive knowledge of the Viking ways, and if he has not come to believe in their gods yet at this point, then his appreciation of their folklore can be noticed in the way he speaks about Thor in this instance. He speaks about Thor respectfully, even somewhat admiringly, calling him "mighty" and a "slayer of frost and fire".

However, Athelstan does not yet know all about the Viking ways, and this becomes clear later on in this episode when he asks Ragnar about the many animals that have been brought to the temple. Ragnar tells him they are to be sacrificed to the gods and that they have brought nine of each kind to do so. Then, Athelstan notices an empty pen and asks Ragnar: "And this?" Ragnar tells Athelstan: "It's for all the humans that have been chosen." Athelstan seems to need a moment to fully comprehend what Ragnar has just told him, but when he does, we see his face take on an expression of complete and utter shock, as he staggers away from the pen in which the human sacrifices will be held. Judging from his reaction when Ragnar told him there would be human sacrifices, this is not something Athelstan is accustomed to or even agrees with. This is quite interesting, as Athelstan's religious beliefs, namely Christianity, are based on the fact that Jesus Christ voluntarily sacrificed himself at the cross (see, for instance, Matthew 27, pp. 32-56). Athelstan keeps his opinions to himself, however, and in a later scene, his is seen partaking in the festivities again.

Athelstan does not know that he is, in fact, one of the humans who are supposed to be sacrificed. Near the end of the episode, the Seer brings Athelstan to the temple, and he is questioned by the priest and asked to renounce his faith three times. This can be likened to the denial of Peter, who also denied Christ three times (Matthew 26, pp. 69-74). The exchange is transcribed here in full:

Priest: Have you come here of your own free will?

\section{Athelstan: Yes}

Priest: At first, I was suspicious of you. I sensed something, so I spoke to Lord Ragnar. He told me your story. That you were a priest, that you were a Christian and worshipped a god called Jesus Christ. Is that true?

Athelstan: Yes.

Priest: And do you still worship this god? Are you still in your heart a Christian?

Athelstan: No.

Priest: Say again. 
Athelstan: No.

Priest: And a third time, say it.

Athelstan: No.

Priest: You know why you're here, don't you? You have been brought here as a sacrifice to the gods.

Athelstan is shocked, and in a reflex, he wants to touch the bracelet he wears on his left wrist. This is noticed by the priest, who takes his arm and looks at the bracelet. It is a bracelet with a cross bangle on it. He says nothing and lets go of Athelstan's arm. Athelstan then quickly leaves the temple.

In the next scene, the Seer informs Ragnar and his kinsmen of the following: "I have come to tell you that the sacrifice of this man will not please the gods. He is neither willing nor is his faith acceptable to Odin. His heart is corrupt. He has not renounced his false god."

A couple of elements are of importance in this scene. The very first is the fact that Athelstan is asked to renounce his faith in Jesus Christ three times. This bears a similarity to the denial of the apostle Peter, who also denied Christ three times, as was predicted by Christ during the Last Supper (Matthew 26:33-35). In this, we see, again, how Athelstan functions as a narrative focal point in which differences and similarities between the two worlds presented in the series come to the fore. Even though renouncing his faith three times refers directly to the denial of Peter, the fact that he does renounce his faith and does this so easily is also telling with regards to his position in Norse society. As a valued member of this society, it is expected of him to share their beliefs and to have let go of his own previous beliefs, even though he was a monk and was raised in a completely different belief system.

Athelstan seems to have incorporated both belief systems in his life, at this point. He has come to see the Norse way of things and understand and value it, but, given the fact that he still wears a bracelet with a cross bangle attached to it, he also has not fully given up his Christian faith at this point yet, thereby signaling both the similarities and the differences between the two, because even though both societies have a strong belief system in place, these systems are, at their core, very different. This has caused the Seer to state that Athelstan's faith is not acceptable to Odin and that his heart is corrupt. For both types of society, only their beliefs constitute the truth. Those who believe something else are corrupt and are heretics. This response is, in the end, a very similar one in both societies, even though it has its origin in different beliefs.

\subsection{Crucifixion and Religious Turmoil}

A similar response to Athelstan's beliefs can be seen in S2E4 when he is crucified. This time, the response is not to his Christian beliefs but to his Norse ones. The scene begins with an image of nails and a hammer being dropped into the grass. The camera then shows us a close-up of Athelstan's face, who is beaten and bloodied and has been made to wear a crown of thorns, just like Jesus Christ. He is made to lie down on the cross and then his hands and feet are nailed to the cross. While this is happening, one can hear Athelstan scream out in pure agony. The cross is then raised and we then see the full extent of Athelstan's injuries, as most of his body is covered in blood.

The cross is surrounded by a group of people, and from among them, Bishop Edmund steps forward: "Edmund: Here is your destiny, apostate. You are being crucified in the name of our Savior Jesus Christ. Amen." Athelstan then begins praying. He prays the paternoster, in Latin. It is at this moment that King Ecbert arrives at the scene, just when a soldier carrying a spear is about to deliver the final blow to Athelstan. Do also note the similarities with the way Jesus Christ died upon the cross. They cannot be missed in this scene and point again to the way in which Athelstan functions as a kind of narrative focal point within the series, a character in which both realms, that of the Vikings and that of Christianity, are united. 
The king orders the soldier to wait and an exchange follows between the king and Bishop Edmund:

King Ecbert: Must we really kill this man?

Bishop Edmund: He is an apostate. He has denied our savior, Jesus Christ and returned to pagan and evil ways. He has murdered good Christians. I say he should die. I say he should be crucified. What do you all say?

Crowd: Crucify him!

King Ecbert: Cut him down.

By ordering Athelstan to be saved from dying at the cross, King Ecbert goes directly against the wishes not only of the bishop, but also against those of the crowd. He has chosen to save the life of someone who is seen as an apostate, someone who has denied Christ. In doing this, King Ecbert has given Athelstan the chance to, again, become a kind of human bridge between the two worlds, having gained both King Ecbert's trust as well as Ragnar's, thereby being able to communicate messages between the two leaders, for instance. He becomes an ally to both.

Athelstan then enters a time of religious turmoil, as he is unsure what he should believe in. He has visions which always have a strong Christian theme, but at the same time, he also feels that the Norse gods are very real, causing him to say, in the ninth episode of the second season, that: "in the gentle fall of rain from heaven, I hear my God, but in the thunder I still hear Thor". This indicates that he has come to a position of in-betweenness, which is finally resolved when Athelstan has joined the Vikings again, of his own free will this time. It is in the sixth episode of the third season that Athelstan receives what he believes to be a sign from above, and he responds in the following manner:

“Oh, Lord. Lord. Praise the Lord! I've asked for a sign. You have given me a sign.

You've answered my prayers. I was blind, but now I see. I was dead, but ... I'm reborn. Father. Hear my prayer and let my cry come unto thee."

This indicates that Athelstan is ready to let go of the Norse gods and accept Christianity back into his life again. In fact, he is overjoyed to do so. The episode then cuts to a new scene, in which we can see Athelstan performing a kind of baptism on himself. He is wearing a necklace with a cross pendant that he was not wearing before, and he is walking into the water and pouring water onto his head and face. More importantly however, is that he removes the bracelet from his left arm that indicates that he is one of Ragnar's kinsmen and throws it into the water as well. This further indicates that Athelstan is taking on a new identity, one that can no longer co-exist with his Viking identity, and therefore, he lets go of it.

Athelstan informs Ragnar that he has rediscovered his faith and has become a Christian again. He even proposes to leave Kattegat right away, but Ragnar is firmly against this, telling Athelstan that he cannot leave because he loves him. Ragnar seems to be the only one who can truly accept Athelstan's differing belief. The other Vikings have a harder time doing so.

At the end of this same episode, we see Athelstan kneeled in front of a cross, praying. When he is finished and has said his last "amen", he looks to his side and says "Flóki". Flóki responds with "Priest". Athelstan already seems to know what will happen, as he looks to the cross again and says "Lord, receive my soul" and raises his arms, waiting for Flóki to indeed deliver the blow that will end his life. This soon follows and Athelstan falls to the floor, dead.

What is important to note here is that Flóki's religious zeal was always more intense than that of the other Vikings in the series. Thus, it is quite natural that Flóki should be the one to murder Athelstan, as Athelstan's conversion back to Christianity is most difficult for him to deal with. To deal with what Flóki considered heresy, Athelstan had to die. This death is perhaps most telling of all with regards to the series' stance on Christianity. The Christians always seem to lose to the Vikings anyways and rarely come away unscathed 
in raids, for instance. Athelstan's death can be seen as a prime example of this dynamic. As soon as he reverts back to his old faith, he is murdered for it, and thus, Athelstan becomes martyred (Johnson and Zurlo 2014), as he is willing to die for his faith. One might even argue that Athelstan's martyrdom was voluntary in nature (Middleton 2013) as he was well aware of Flóki's views and made no secret of his rediscovery of his old faith, as well as not resisting when Flóki came into his home to kill him. Interestingly, Athelstan's sacrifice is not acknowledged in the series. Rather, Athelstan's death can be seen as yet another way in which the series portrays Viking culture being superior to that of Christianity.

\section{Discussion and Conclusions}

In this article, I set forth to analyze the role the character Athelstan has played in the television series Vikings as a synthesis between the two opposing worldviews in the series. The series is part of the ongoing trend of portraying Viking society in both a fictionalized and romanticized manner.

The series makes it a point to show that Christian society is inferior to the Vikings' and only has a role to play as victims. In other words: a religion that is still alive today is being portrayed very negatively in the series, whereas a religion that is no longer in practice is romanticized. This indicates a very negative view on Christianity indeed, as the only religion worthy of being painted positively in Vikings is one that is no longer in use, rather than the one that is still around today. Both belief systems and values of the societies in which he has lived manifest within the character Athelstan. This points to a possibility for reconciliation between the two, as it is this character who, at the same time, shows how similar and different they truly are.

The series makes no claims as to the moral or spiritual superiority of one religion over the other. Instead, it emphasizes how each group deems the other's beliefs inferior to their own. This focus on spirituality and religion, which often comes to the fore throughout the series, can be seen as an example of digital religion (Hoover and Echchaibi 2014). The series offers a digital exploration of the religions, rather than this exploration taking place in person. This, in turn, indicates that the series can be seen as a liberatory space. It offers a space through which people can reflect on their own beliefs, without having to face the scrutiny of their peers. Moreover, while Hoover and Echchaibi (2014) relate digital religion to places on the Internet, the series shows that digital religion can also take place via other media, such as a television series. When we think of the digital, it is easy to immediately think of places on the Internet such as message boards, as Hoover and Echchaibi (2014) and Pennington (2018) have shown. However, with the advent of websites such as Netflix, this distinction has become less easy to make, as television series have become digital as well and can be and are enjoyed online.

It is interesting to note that although the series makes no claims as to the moral or spiritual superiority of either belief system, it does paint Christianity in a negative light and does so consistently throughout the series. It is, therefore, not a neutral place of reflection, but rather, the series offers a profound critique of Christianity, contrasted with a romanticization of Viking culture and mythology.

This portrayal falls in line with a general romanticization of Viking culture in popular culture. The Vikings seem to have it all, whereas in comparison, Christianity and its perceived restrictions and imperfections do not look as appealing. A television series such as Vikings, then, becomes a site in which various visions on religion can be explored and discovered, but which ultimately puts one view on religion, regarding Christianity in particular, forward in a very clear and decisive manner.

Therefore, although Pennington (2018) states that digital media offer a place where reflection can take place away from the scrutiny of, for instance, friends and family, this leaves out the portrayals of religion offered up on these media, which can also influence the direction one's reflections might take. Digital media are not neutral sites without meaning — rather, they are filled to the brim with it. 
Although this article has only employed a small sample, my analysis has shown that Viking culture is portrayed as having the upper hand over Christianity in the popular television series Vikings. This, then, can provide an area of further research into how other forms of popular culture portray Christianity, especially in relation to other belief systems, such as that of the Vikings. Moreover, this can provide a basis for a larger-scale analysis on the portrayal of Christianity in television and film and the narratives which are used to contrast Christianity with other religions.

In this particular case, the Vikings always come out on top, which makes a synthesis between the two realms-although it seemed feasible for some time, while Athelstan was still alive-impossible. Athelstan's death can be seen as a prime example of this dynamic within the series. As soon as he goes back to his old faith, he is murdered for it by Flóki. As Flóki delivered the final blow to end Athelstan's life, so, too, did he deliver the final blow to any possibility of a synthesis between the two realms, that of Christianity and that of Viking society, within the series. Not even Athelstan being martyred (Johnson and Zurlo 2014) was enough to inspire a kinder view on Christianity. In the end, the Vikings always win.

Funding: This research received no external funding.

Institutional Review Board Statement: Not applicable.

Informed Consent Statement: Not applicable.

Conflicts of Interest: The author declares no conflict of interest.

\section{References}

Bal, Mieke. 1985. Narratology. Introduction to the Theory of Narrative. Toronto: University of Toronto Press.

Bosman, Frank. 2017. The Incarnated Gamer: The Theophoric Quality of Games, Gaming and Gamers. In Boundaries of Self and Reality Online. Edited by Jayne Gackenback and Johnathan Bown. London: Elsevier, pp. 187-203.

Bosman, Frank. 2019. Gaming and the Divine. A New Systematic Theology of Video Games. London: Routledge.

Bullough, Vern. 1977. Sex Education in Medieval Christianity. Journal of Sex Research 13: 185-96. [CrossRef]

Erwich, René. 2020. “Someday Our Gods Will Be Friends". The Vikings Series as Embodiment of Religion and Liquefaction of Meaning. Journal for Religion, Film and Media 6: 103-26. [CrossRef]

Goris, Harm. n.d. Vroege Kerk: Hoofdzonden en Erfzonde. Available online: https://pure.uvt.nl/ws/portalfiles/portal/6875754/20 15_traditionele_beelden_van_zonde.docx (accessed on 15 January 2021).

Herman, Luc, and Bart Vervaeck. 2005. Vertelduivels. Handboek Verhaalanalyse. Nijmegen: Vantilt.

Holland, Luke. 2019. Game of Groans: How Boring Historical Accuracy ruined Vikings. Available online: https:/ / www.theguardian. $\mathrm{com} / \mathrm{tv}$-and-radio/2019/jul/15/jump-the-shark-vikings (accessed on 26 February 2021).

Holman, Katherine. 2003. Historical Dictionary of the Vikings. Lanham: Scarecrow Press.

Hoover, Stewart, and Nabil Echchaibi. 2014. Media Theory and the "Third Spaces of Digital Religion". Available online: https: //www.researchgate.net/publication/287644204_The_Third_Spaces_of_Digital_Religion (accessed on 7 March 2021).

IMDb. n.d. Vikings (2013-2020). Awards. Available online: https:/ /www.imdb.com/title/tt2306299/awards (accessed on 26 February 2021).

Johnson, Todd, and Gina Zurlo. 2014. Christian Martyrdom as a Pervasive Phenomenon. Society 51: 679-85. [CrossRef]

McClure, Jane. n.d. Benedictine Way of Life. Available online: https://stellamaris.nsw.edu.au/wp-content/uploads/2015/06/ benedictine-way-of-life.pdf (accessed on 15 January 2021).

McLeod, Shane. 2019. Shieldmaidens in Anglo-Saxon England: Historical Possibility or Wishful Thinking? In Vikings and the Vikings. Essays on Television's History Channel Series. Edited by Paul Harwick and Kate Lister. Jefferson: McFarland \& Company Inc., pp. 77-93.

Middleton, Paul. 2013. Early Christian voluntary martyrdom: A statement for the defence [sic]. Journal of Theological Studies 64: 556-73. [CrossRef]

Moen, Marianne. n.d. Gender and Sexuality in the Viking Age. Available online: https:/ /www.stk.uio.no/english/research/PRIDE/ gender-and-sexuality-in-the-viking-age.html (accessed on 15 January 2021).

Nieuwe Bijbelvertaling. 2004. Heerenveen: Uitgeverij NBG.

O'Neill, Phelim. 2014. Vikings: Don't Dismiss This Show as Game of Thrones-Lite. Available online: https:/ /www.theguardian.com/ tv-and-radio/tvandradioblog/2014/may/23/vikings-review-history-channel-game-of-thrones (accessed on 26 February 2021).

Pagels, Elaine. 1988. Adam, Eve and the Serpent. New York: Random House.

Pennington, Rosemary. 2018. Social Media as Third Spaces? Exploring Muslim Identity and Connection in Tumblr. Available online: https://journals-sagepub-com.proxy.library.uu.nl/doi/10.1177/1748048518802208 (accessed on 7 March 2021). 
Phelpstead, Carl. 2007. Hair Today, Gone Tomorrow: Hair Loss, the Tonsure, and Masculinity in Medieval Iceland. Scandinavian Studies 85: 1-19. [CrossRef]

Puchalska, Joanna. 2015. Vikings Television Series: When History and Myth Intermingle. The Polish Journal of the Arts and Culture 15: 89-105.

Raffield, Ben, Neil Price, and Mark Collard. 2017. Polygyny, Concubinage and the Social Lives of Women in Viking-age Scandinavia. Viking and Medieval Scandinavia 13: 165-209. [CrossRef]

Saunders, Robert. 2014. Primetime Paganism: Popular Culture Representations of Europhylic Polytheism in Game of Thrones and Vikings. Correspondences 2: 121-57.

Trafford, Simon. 2020. Viking Metal. In The Oxford Handbook of Music and Medievalism. Edited by Stephen Meyer and Kirsten Yri. Oxford: Oxford University Press, pp. 568-84.

Trafford, Simon, and Aleks Pluskowski. 2007. Antichrist Superstars. The Vikings in Hard Rock and Heavy Metal. In Mass Market Medieval. Essays on the Middle Ages in Popular Culture. Edited by David Marshall. Jefferson: McFarland Books, pp. 57-73.

Tristram, Kate. n.d. The Religious History of Lindisfarne. Available online: https://www.lindisfarne.org.uk/general/relhist.htm (accessed on 15 January 2021).

Tromans, Dom. 2015. The Making of a Legend the Saga of Ragnar Lothbrok and the TV Series 'Vikings'. Available online: https: / / www.medievalists.net/2015/11/the-making-of-a-legend-the-saga-of-ragnar-lothbrok-and-the-tv-series-vikings / (accessed on 8 January 2021).

Verstraten, Peter. 2009. Film Narratology. Toronto: University of Toronto Press. 